\title{
Polyadenylation site heterogeneity in mRNA encoding the precursor of the barley toxin $\beta$-hordothionin
}

\author{
Carlos Hernández-Lucas, Joaquin Royo, Javier Paz-Ares, Fernando Ponz, \\ Francisco García-Olmedo and Pilar Carbonero* \\ Departamento de Bioquímica. ETS Ingenieros Agrónomos-UPM, 28040 Madrid, Spain
}

\begin{abstract}
Two cDNA clones, pTH2 and pTH3, encoding the precursor of the barley toxin $\beta$-hordothionin have been identified and their nucleotide sequences determined. These sequences are identical, except that pTH2 is 22 bp longer than pTH 3 at the $5^{\prime}$ end and that the cleavage/poly(A) site of the mRNA represented by pTH3 is 4 positions further downstream from the single $5^{\prime}$-AAUAAA- $3^{\prime}$ polyadenylation signal than that of the pTH2 mRNA. In contrast, the cleavage/poly(A) site of the $\alpha$-hordothionin mRNA is 30 positions downstream from a second polyadenylation signal. The deduced amino acid sequence of the $\beta$-hordothionin precursor differs from that of $\alpha$-hordothionin at 13 out of 127 positions.
\end{abstract}

(Barley endosperm) Plant toxin $\quad$-Hordothionin Cleavage/poly (A) site cDNA sequence

\section{INTRODUCTION}

Thionins are peptide toxins present in cereal endosperm which are closely related to the viscotoxins from the mistletoes (Loranthaceae) and to crambin, a non-toxic protein from crambe (Cruciferae). Although orally innocuous, they are active against cultured mammalian cells, yeast and phytopathogenic bacteria (review [1]). Two thionins, respectively designated $\alpha$ - and $\beta$-hordothionins, have been reported in barley $[2,3]$. Hordothionins are synthesized by membrane-bound polysomes as much larger precursors that are processed in two steps: the co-transiational excision of a leader sequence and the post-translational cleavage of a $\mathrm{C}$ terminal acidic peptide $[4,5]$. The cDNA corresponding to the precursor of $\alpha$-hordothionin has been recently described [5]. We now report the characterization of two cDNA clones encoding the precursor of $\beta$-hordothionin and present evidence of heterogeneity at the polyadenylation site.

\section{MATERIALS AND METHODS}

A cDNA library of developing barley endosperm (cv. Bomi), collected 20 days after anthesis, was constructed in plasmid pBR322 (PstI site; $\operatorname{poly}(\mathrm{G}) / \mathrm{poly}(\mathrm{C})$ homopolymeric tailing) as described [5]. The library was screened for thionin clones in two stages: a preliminary screening using a radioactive ss-cDNA probe, synthesized by reverse transcription from RNA enriched for thionin precursor messenger activity, and a final screening by hybrid-selected translation and identification of translation products with monospecific antibodies, following previously reported methods [4,5]. Restriction mapping and DNA sequencing [6] were also carried out as in [5].

\section{RESULTS AND DISCUSSION}

To identify cDNA clones encoding $\beta$-hordothionin, the clones identified by hybrid-selected translation were further characterized by restriction mapping and 3 were found to be different from the previously described $\alpha$-hordothionin 


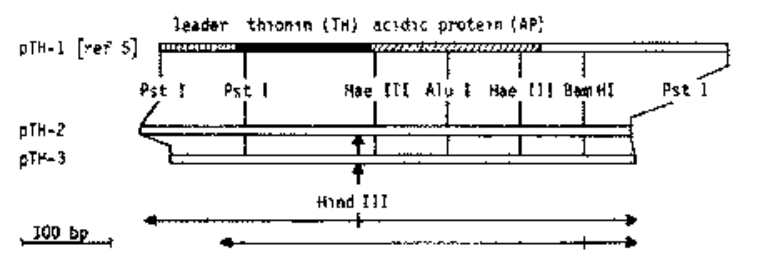

Fig.1. Restriction maps and sequence strategy of clones pTH2 and pTH3. The structure of clone pTHI [5] is presented for comparison. Horizontal arrows indicate the direction and extent of sequence determination.

leader

B-hordothionin pTH2 AGC AAG GEC CTC AAG GGT GTG ATG GTG TGT TTA CTC ATA CTG GGG TTG GTT CTG GAA CAT GTG CAA PTH3 met val cys teu leu 1le leu gly leu val leu glu his val gln

a-hordothionin DTHI (ref. 5)

pTH2 GTA GAA GGC AAG AGT TGC TGC AGG AGC ACC CTA GGA AGA AAT TGC TAC AAC CTT TGC CGC GTC CGT GGT GCT CAG

PTH3 Val glu gly|lys ser cys cys arg ser thr lew gly arg asn cys tyr asn leu cys arg val arg gly ala gin 40 ptHl

PTH2 AAG TTA TGC GCA AAC GCG TGT AGG TGT AAA CTC ACA AGT GGC CTA AAA TEC TCI TCA AGC TIC CCA AAA TTG GCC

lys leu cys ala asn ala cys arg cys lys leu thr ser gly leu lys cys pro ser ser phe pro lys leu ala

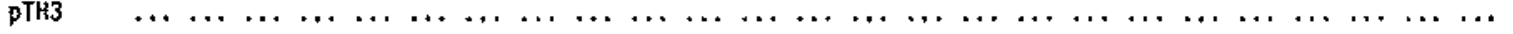

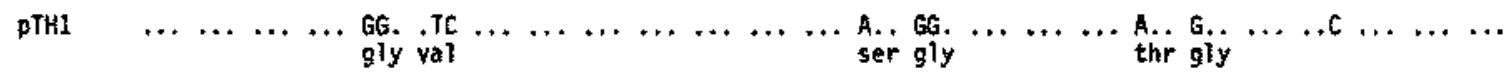
PTH2 ITT GTG TCA AAC FCA GAT GAA CCA GAC ACC ATC GAC TAT TGC AAC TTG GGG IGT AGG GCT ICC ATG TGT GAC TAC
leu val ser asn ser asp glu pro asp thr 11e asp tyr cys asn leu gly cys arg ala ser met cys asp tyr g0

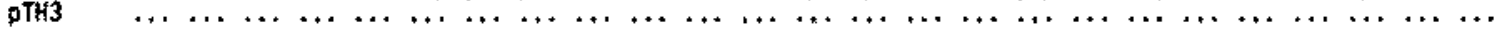

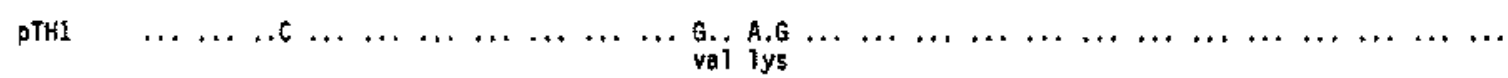

PTH2 ATG GTC AAC GCA GCT GCT GAC GAC GAA GAG ATG AAA CTC TAT GTG GAA CAT TGT AGT GAT GCT TGT GTC AAT TTC met val asn ala ala ala asp asp glu giu met lys leu tyr val glu his cys ser asp alo cys val asn phe 115

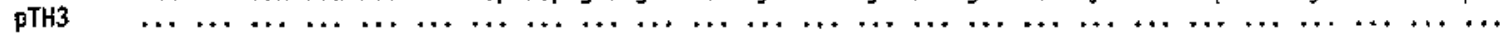

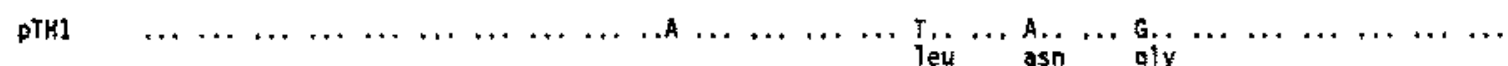

PTH2 TGT AAC GGT GAT GTT GGC CTC ACA TCC CTT ACT GCC TAA TGA YGT GTA TCC ATG GTC TGA GAT TTC AAA GGG CAA cys osn gly asp val-gly leu thr ser leu thr ald tor ter

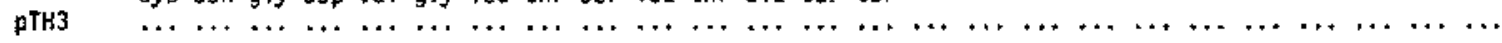

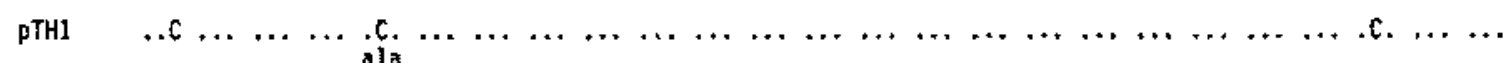

DTH2 GGT TGT ATC TCA CET TTG CGT TCE ATA APA TIG GAT CCC ATC GAG AGT (A)

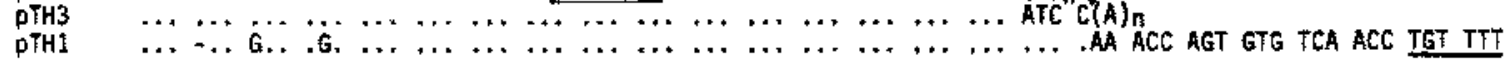

PIH) ATG TGT GTG TAT ITT CAT TCE TTG ITC GAA TAR ARG CCG TCA TAA TGA ATG CCA TGT TEC TGC C(A)

Fig.2. Nucleotide sequences and predicted amino acid sequences of clones pTH2 and pTH3, encoding the precursor of $\beta$-hordothionin, are aligned with those of the $\alpha$-hordothionin clone pTH1 [S]. Amino acids are numbered from the Nterminal. The beginning of the leader sequence, the mature protein (TH), and the C-terminal acidic peptide (AP) are indicated. Identity is indicated by a dot $(\cdot)$, deletion by a dash $(-)$, polyadenylation signals are boxed and numbered, cleavage/poly(A) sites are marked by a vertical arrow $(\emptyset)$, and the $G / T$ cluster downstream from the first polyadenylation signal is underlined. 
cDNA clone pTH1 [5]: inserts in clones pTH2 and pTH3 had an internal HindIII site (absent in pTH1) and an internal PstI site was missing in the insert of clone pTH4. The inserts of these clones were subjected to nucleotide sequencing according to Maxam and Gilbert [6] and clone pTH4 was found not to include a thionin sequence. Restriction maps and sequencing strategies for clones pTH2 and pTH3 are shown in fig.1. The nucleotide sequences and the amino acid sequences deduced from them for both inserts are presented in fig.2. The previously published sequence of the insert in clone pTH1 [5] is also presented for comparison. The two inserts are identical, except that pTH2 is 22 bp longer than pTH3 at the 5'-end of the sequence, and that pTH3 has the poly(A) site 4 bp further downstream, with respect to the 5 ' AAUAAA-3' signal, than clone pTH2. The amino acid sequence deduced for the $\beta$-hordothionin precursor (127 amino acids in length) is very similar to that of $\alpha$-hordothionin: a leader sequence of 18 amino acids, which differs at position 13 , followed by the sequence of the mature $\beta$ hordothionin, which has 6 substitutions (positions $45,46,54,55,59$ and 60 of the precursor) and a C-terminal acidic peptide with different residues at positions $76,77,105,107,109$ and 120 of the precursor. It should be noted that the sequence deduced for $\beta$-hordothionin, which has been confirmed in both clones, differs from that previously obtained by direct protein sequencing by Mak (see [3]) at positions 33, 56, 59 and 60 of the precursor (positions 15, 38, 41 and 42 of the mature protein). The sequence proposed by Mak [3] for $\alpha$-hordothionin has been found to be erroneous precisely at positions 38,41 and 42 of the protein $[5,7]$ so it is not unlikely that a systematic error affected both determinations.

The observed variability at the non-coding $3^{\prime}$ ends of the sequences in fig. 2 merits attention in connection with recent findings about factors determining cleavage/polyadenylation sites of premRNA (review [8]). The poly(A) tail in $\alpha$-hordothionin mRNA is at position 30 downstream from the second $S^{\prime}$-AAUAAA-3' polyadenylation signal, whereas the $\beta$-hordothionin mRNAs, represented by clones pTH2 and pTH3, have the poly(A) at positions 19 and 23 downstream from a single polyadenylation signal that corresponds to the first signal of the $\alpha$-hordothionin mRNA.
Alternative use of multiple polyadenylation signals has been repeatedly observed within gene families and even within a single transcription unit [8-13]. There is evidence that the selection of a cleavage/ poly(A) site can be a regulatory event controlling gene expression and that, in some cases, has an influence on subsequent processing events in preceding regions of the RNA molecule [8-10]. The sequences between the first poly(A) signal and the corresponding cleavage sites are identical in the 3 clones, so the failure to use this signal in $\alpha$ hordothionin mRNA has to be ascribed to differences in the sequences between the translation termination codons and the signal ( 3 point mutations and a 1-base deletion) or to differences in the sequence downstream from the potential cleavage sites. However, it should be pointed out that, within the 30 positions downstream from these potential cleavage sites in $\alpha$-hordothionin mRNA, there is the appropriate $\mathrm{G} / \mathrm{T}$ cluster (underlined in fig.2), which together with the 5'-AAUAAA-3' signal, is thought to be required for cleavage [8].

The existence of multiple cleavage/poly(A) sites under the influence of a single signal, as reported here for $\beta$-hordothionin mRNAs, is a more unusual case. Fitzgerald and Shenk [14] found that a few of the mutants with deletions between the signal and the cleavage site, in a SV-40 transcription unit, yielded multiple cleavage sites. Naturally occurring similar situations have been reported for the hepatitis B virus surface antigen [15] and for a few eucaryotic genes, namely bovine prolactin [16], mouse ribosomal protein L30 [17] and chicken pro- $\alpha_{2}$ (I)-collagen [18]. This is, to our knowledge, the first reported case in the plant kingdom.

\section{ACKNOWLEDGEMENTS}

This work was supported by the Comision Asesora de Investigación Cientifica y Técnica (grant no. 1344). The authors thank C. Rojas and D. Lamoneda for their help.

\section{REFERENCES}

[1] Garcia-Olmedo, F., Carbonero, P. and Jones, B.L. (1982) Adv. Cereal Sci. Technol. 5, 1-47.

[2] Redman, D.G. and Fisher, N. (1969) J. Sci. Food Agric. 20, 427-434.

[3] Lecomte, J.T.J., Jones, B.L. and Llinas, M. (1982) Biochemistry 21, 4843-4849. 
[4] Ponz, F., Paz-Ares, J., Hernández-Lucas, C., Carbonero, P. and Garcia-Olmedo, F. (1983) EMBO J. 2, $1035-1040$.

[5] Ponz, F., Paz-Ares, J., Hernández-Lucas, C., Garcia-Olmedo, F. and Carbonero, P. (1986) Eur. $\mathrm{J}$. Biochem., in press.

[6] Maxam, A.M. and Gilbert, W. (1980) Methods Enzymol. 65, 499-560.

[7] Ozaki, Y., Wada, K., Hase, T., Matsubara, H., Nakanishi, T. and Yoshizumi, H. (1980) J. Biochem. (Tokyo) 87, 549-555.

[8] Birnstiel, M.L., Busslinger, M. and Strub, K. (1985) Cell 41, 349-359.

[9] Mather, E.L., Neison, K.J., Haimovich, J. and Perry, R.P. (1984) Cell 36, 595-605.

[10] Danner, D. and Leder, P. (1985) Proc. Natl. Acad. Sci. USA 82, 8658-8662.
[11] Darnell, J.E. (1982) Nature 297, 365-371.

[12] Nevins, J.R. (1983) Annu. Rev. Biochem. 52, 441-466.

[13] Rosenfeld, M.O., Amara, S.G. and Evans, R.M. (1984) Science 225, 1315-1320.

[14] Fitzgerald, M. and Shenk, T. (1981) Cell 24, 251-260.

[15] Simonsen, C.C. and Levinson, A.D. (1983) Mol. Cell Biol. 3, 2250-2258.

[16] Sasavage, N.L., Smith, M., Gillam, S., Woychick, R.P. and Rottman, F.M. (1982) Proc. Natl. Acad. Sci. USA 79, 223-227.

[17] Wiedemann, L.M. and Perry, R.P. (1984) Mol. Cell. Biol. 4, 2518-2528.

[18] Aho, S., Tate, V. and Boedtker, H. (1983) Nucleic Acid Res. 11, 5443-5450. 